\title{
Comparison of budesonide and beclomethasone dipropionate for treatment of asthma
}

\author{
C SPRINGER, ${ }^{*}$ A AVITAL, ${ }^{*}$ CH MAAYAN, ${ }^{*}$ A ROSLER, $\dagger$ AND S GODFREY* \\ Departments of *Paediatrics and †Endocrinology and Metabolism, Hadassah University Hospital, \\ Jerusalem, Israel
}

SUMMARY Beclomethasone dipropionate (BDP) and budesonide (BUD) were each given in a dose of $200 \mu \mathrm{g}$ twice daily by metered dose inhaler to 10 asthmatic children already dependent on treatment with steroids. In a double blind randomised crossover study each course lasted one month. No clinically important differences were found between the two treatments when symptom scores, symptom free days, additional use of salbutamol, and results of lung function tests were considered. Metyrapone mildly reduced the plasma concentration of 11-deoxycortisol in two patients during treatment with budesonide, and in four during treatment with beclomethasone. It is concluded that although they are usually safe, both drugs may cause mild adrenal suppression when given in a dose of $200 \mu \mathrm{g}$ twice daily.

Inhaled beclomethasone dipropionate (BDP) is effective treatment for asthma in children. ${ }^{1-4}$ Recently a new non-halogenated corticosteroid aerosol, budesonide, has been shown to be effective in treating chronic asthma in adults ${ }^{5}$ and in children. ${ }^{67}$ Budesonide need only be given twice daily, compared with the four doses of beclomethasone that are usually required each day.

We therefore set up a trial to compare the efficacy of the two drugs when both were given twice daily to asthmatic children already dependent on treatment with steroids. In addition, we evaluated the influence of the two drugs on the function of the pituitary adrenal axis in view of reports that BDP could cause adrenal suppression. ${ }^{89}$

\section{Patients and methods}

Ten asthmatic children aged between 9 and 15 and already dependent on treatment with steroids were included in the study. They were all within the normal ranges of height and weight for their ages. Nine patients had already been receiving BDP $(400$ $\mu \mathrm{g}$ daily) for two months to four years (mean 1.7 years), and one patient started treatment with inhaled corticosteroids at the beginning of this study. No patient had received oral steroids for more than a total of 20 days in the previous year, and none for the last month.

The trial was a double blind randomised crossover study with one month each of treatment by BUD or BDP $200 \mu \mathrm{g}$ twice daily using a conventional pressurised aerosol without a spacer. The treatment protocols were as follows: (i) BDP $200 \mu \mathrm{g}$ (four puffs) twice daily and placebo BUD four puffs twice daily (every 12 hours); and (ii) BUD $200 \mu \mathrm{g}$ (four puffs) twice daily and placebo BDP four puffs twice daily. The order of the treatments was decided at random. In addition to BUD and BDP, the children were allowed free use of salbutamol given by pressurised aerosol. Each child used a standard diary card to record diurnal and nocturnal symptoms and drug use throughout the trial. ${ }^{10}$ In addition, peak expiratory flow rates were measured each morning and evening before taking the drugs using the Wright Mini Peak Flow Meter. At the end of each month measurements of forced expiration and whole body plethysmography were made in the laboratory.

A 24 hour urine collection was made at the end of each month for measurement of the excretion of tetrahydrocortisone glucosiduronate (THE) and tetrahydrocortisol glucosiduronate (THF) by radioimmunoassay. " Concentrations of cortisol, adrenocorticotrophic hormone (ACTH) and 11-deoxycortisol in plasma were measured at the end of each month of treatment before and 10 hours after a single oral dose of $30 \mathrm{mg} / \mathrm{kg}$ of metyrapone, using a sensitive radioimmunoassay described previously. ${ }^{12-15}$ 
816 Springer, Avital, Maayan, Rosler, and Godfrey

Table 1 Results after taking beclomethasone for one month

\begin{tabular}{|c|c|c|c|c|c|c|c|c|c|c|c|}
\hline & \multicolumn{10}{|c|}{ Case Nos } & \multirow{2}{*}{$\begin{array}{l}\text { Mean } \\
\text { (SEM) }\end{array}$} \\
\hline & $I$ & 2 & 3 & 4 & 5 & 6 & 7 & 8 & 9 & 10 & \\
\hline $\begin{array}{l}\text { No of doses of salbutamol } \\
\text { Days free of symptoms }\end{array}$ & 36 & 0 & 0 & 35 & () & 0 & () & 6 & 6 & 4 & $9(4)$ \\
\hline $\begin{array}{l}\text { (\% of total) } \\
\text { Symptom score }\end{array}$ & 0 & 100 & 79 & 0 & 93 & 100 & 100 & 0 & 86 & 71 & $63(14)$ \\
\hline (\% of maximum) & 26 & 0 & 4 & 24 & 1 & 0 & 0 & 20 & 1 & 7 & $8(3)$ \\
\hline $\begin{array}{l}\text { Peak expiratory flow rate* } \\
\text { Maximum expiratory flow }\end{array}$ & 99 & 112 & 122 & 87 & 108 & 74 & 117 & 68 & 111 & 109 & $101(5)$ \\
\hline $\begin{array}{l}\text { rate at } 50 \% \text { vital capacity* } \\
\text { Forced expiratory volume }\end{array}$ & 59 & 45 & 58 & 62 & 51 & 46 & 63 & 61 & 59 & 74 & $58(3)$ \\
\hline in 1 second ${ }^{*}$ & 86 & 74 & 87 & 90 & 90 & 64 & 91 & 81 & 85 & 101 & $85(3)$ \\
\hline Specific airways conductance* & $\begin{array}{l}\text { Not } \\
\text { done }\end{array}$ & $\begin{array}{l}\text { Not } \\
\text { done }\end{array}$ & 150 & 69 & 41 & 50 & 50 & 100 & 53 & 41 & $69(13)$ \\
\hline
\end{tabular}

${ }^{*}$ Given as $\%$ of predicted value

Table 2 Results after taking budesonide for one month

\begin{tabular}{|c|c|c|c|c|c|c|c|c|c|c|c|}
\hline & \multicolumn{10}{|c|}{ Case Nos } & \multirow{2}{*}{$\begin{array}{l}\text { Mean } \\
(S E M)\end{array}$} \\
\hline & 1 & 2 & 3 & 4 & 5 & 6 & 7 & 8 & 9 & 10 & \\
\hline $\begin{array}{l}\text { No of doses of salbutamol } \\
\text { Days free of symptoms }\end{array}$ & 34 & 0 & 0 & 36 & () & () & 2 & 2 & 8 & 0 & $8(5)$ \\
\hline $\begin{array}{l}\text { (\% of total) } \\
\text { Symptoms score }\end{array}$ & 0 & 100 & 100 & 36 & 86 & 100 & 100 & 14 & 71 & 86 & $69(12)$ \\
\hline (\% of maximum) & 20 & 0 & 0 & 27 & 2 & 0 & 0 & 11 & 4 & 1 & $7(3)$ \\
\hline $\begin{array}{l}\text { Peak expiratory flow rate* } \\
\text { Maximum expiratory flow }\end{array}$ & 97 & 120 & 118 & 87 & 106 & 83 & 120 & 79 & 106 & 110 & $103(4)$ \\
\hline $\begin{array}{l}\text { rate at } 50 \% \text { vital capacity* } \\
\text { Forced expiratory volume }\end{array}$ & 66 & 51 & 68 & 77 & 59 & 60 & 54 & 52 & 51 & 82 & $62(3)$ \\
\hline $\begin{array}{l}\text { in } 1 \text { second* } \\
\text { Specific airways conductance* }\end{array}$ & $\begin{array}{l}92 \\
\text { Not }\end{array}$ & $\begin{array}{l}77 \\
\text { Not }\end{array}$ & $\begin{array}{r}90 \\
120\end{array}$ & $\begin{array}{r}105 \\
49\end{array}$ & $\begin{array}{l}99 \\
46\end{array}$ & $\begin{array}{l}92 \\
72\end{array}$ & $\begin{array}{l}76 \\
70\end{array}$ & $\begin{array}{r}84 \\
100\end{array}$ & $\begin{array}{l}84 \\
35\end{array}$ & $\begin{array}{r}101 \\
35\end{array}$ & $\begin{array}{ll}90 & (3) \\
66 & (11)\end{array}$ \\
\hline
\end{tabular}

${ }^{*}$ Given as $\%$ of predicted value

Table 3 Excretion of tetrahydrocortisol glucosiduronate and tetrahydrocortisone glucosiduronate after taking beclomethasone and budesonide

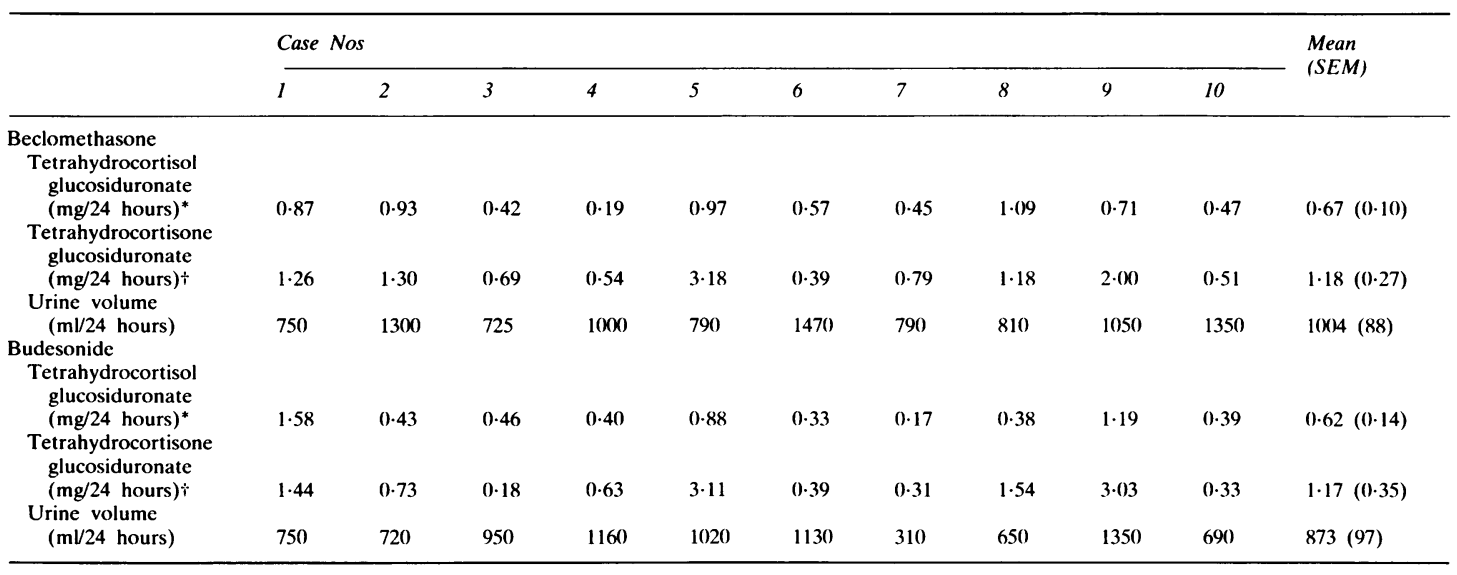

Mean (SD) normal values, $\mathrm{mg} / 24$ hours: ${ }^{*} 0 \cdot 84(0 \cdot 71) ;+1 \cdot 25(0 \cdot 91)$. 
Comparisons between numbers were made using the paired $t$ test, differences being regarded as significant if the $\mathrm{p}$ value was $<0 \cdot 05$.

\section{Results}

Thirteen children entered the trial, but three were withdrawn during the first two weeks because of acute exacerbations of asthma requiring treatment with oral steroids. One child was receiving BUD and the other two BDP. Tables 1 and 2 show that for the remaining 10 patients there were no significant differences between treatments when measurements of forced expiratory volume in one second, maximum expiratory flow at $50 \%$ vital capacity, and specific airways conductance at the end of each month were considered, neither were there any differences in diary symptom score, number of symptom free days, mean morning and evening peak expiratory flow rates, and need for additional salbutamol for the second two weeks of each month.
Table 3 shows the mean rates of excretion of THE and THF inclusive; there were no significant differences between treatments and all the individual values were within the normal ranges with both drugs.

Figures 1 and 2 show the basal concentrations of cortisol, 11-deoxycortisol, and adrenocorticotrophic hormone (ACTH) in plasma before and after a single dose of metyrapone. Concentrations of cortisol and ACTH were within normal limits in both months when BDP and BUD were administered. 11-deoxycortisol increased normally in response to metyrapone in six children receiving BDP and eight receiving BUD. ACTH concentrations increased in most of the patients, but there was no correlation with the concentration of 11-deoxycortisol. The response of cortisol to metyrapone varied.

\section{Discussion}

We have shown that BUD is as effective as BDP for

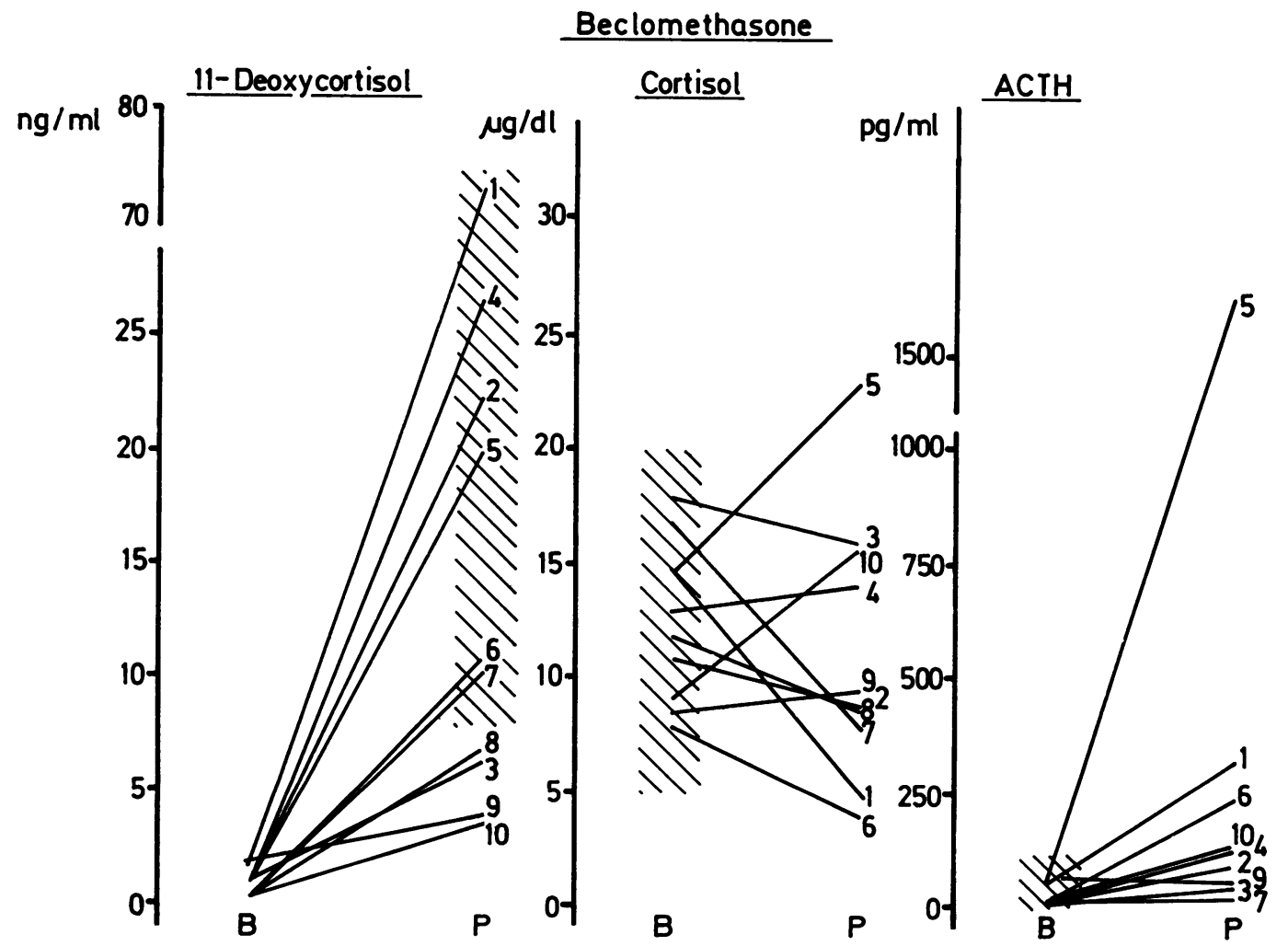

Fig. 1 Serum concentrations of 11-deoxycortisol, cortisol, and adrenocorticotrophic hormone before and after one dose of metyrapone during treatment with beclomethasone.

$B=$ basal; $P=$ after metyrapone; shaded area $=$ mean $(S D)$ normal concentration. 


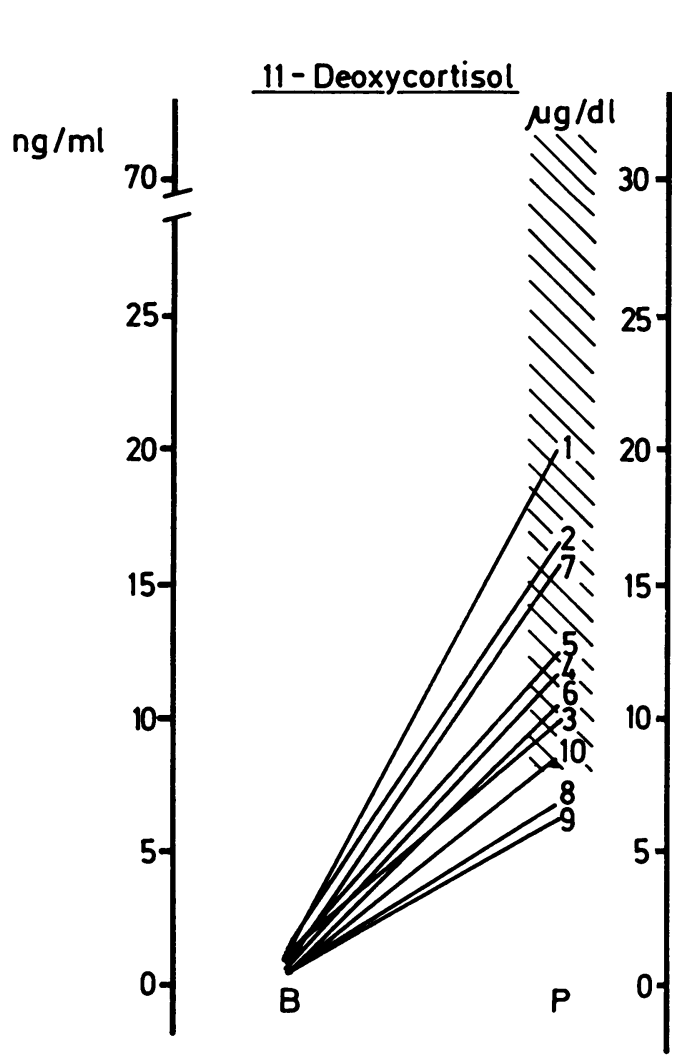

Budesonide

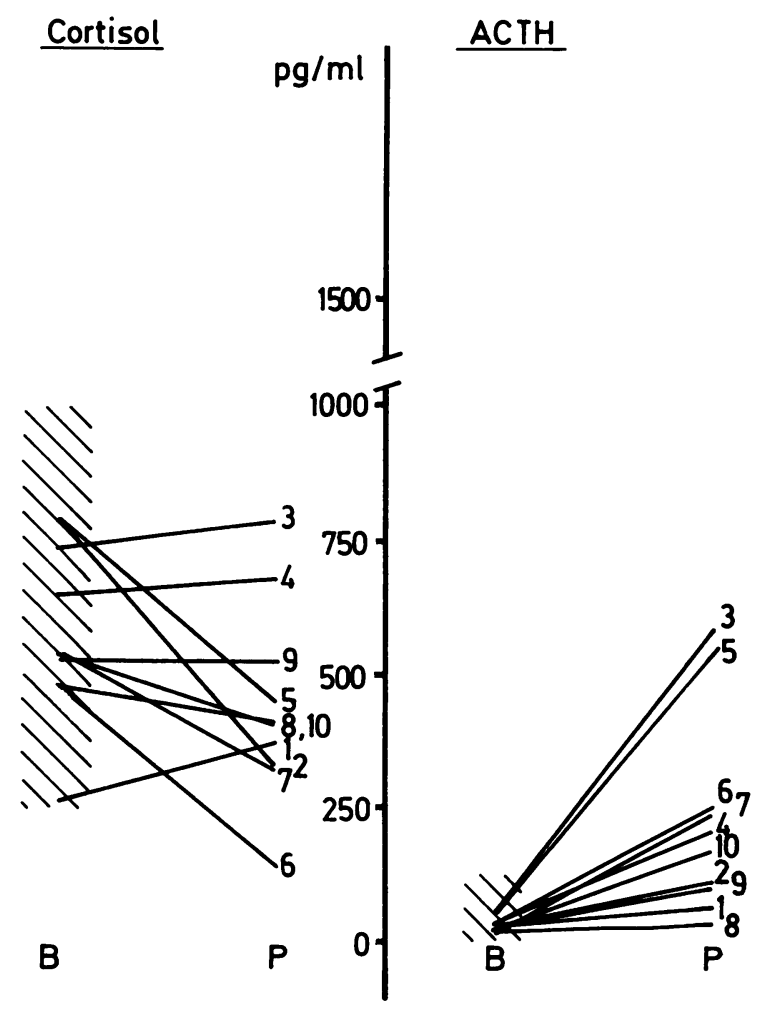

Fig. 2 Serum concentrations of 11-deoxycortisol, cortisol, and adrenocorticotrophic hormone before and after one dose of metyrapone during treatment with budesonide.

$B=$ basal; $P=$ after metyrapone; shaded area $=$ mean $(S D)$ normal concentration.

treating asthma in children dependent on steroid treatment when given in a dose of $200 \mu \mathrm{g}$ twice daily using a standard pressurised inhaler without a spacer.

The efficacy of BUD given twice daily is well established in the treatment of such children. ${ }^{67} \mathrm{We}$ know of only two other published studies, which report that BDP is as effective when given twice daily as it is when given four times daily (Williams $\mathrm{H}$, et al. Abstract presented at 49th Annual Scientific Assembly, Chicago 1983). ${ }^{16}$ Our study shows that either drug can be used successfully twice daily for most asthmatic children who depend on steroid treatment.

Adrenal function was assessed by measuring 24 hour urinary excretion of THE and THF, which have been shown to be good indirect measures for cortisol excretion. " We also measured concentrations of cortisol, 11-deoxycortisol, and ACTH in plasma before and after challenge with metyrapone. Although we have not included a group of normal controls in this study, we have taken normal values from published reports and from experience in our own laboratory. 111415 Urinary excretion THE and THF, and basal concentrations of cortisol and $\mathrm{ACTH}$ in plasma were found during both sets of treatments. The response of 11-deoxycortisol concentrations to a dose of metyrapone was mildly decreased in two patients during treatment with BUD and in four during treatment with BDP. These results suggest that, although safe for most patients, both drugs may moderately suppress the function of the pituitary adrenal axis when given in a dose of $200 \mu \mathrm{g}$ twice daily.

Since this study was undertaken, Law et $\mathrm{al}^{17}$ have shown that nocturnal cortisol excretion rates fall according to dose in children using inhaled steroids. ${ }^{17}$ Further studies of this type are needed 
before any conclusions can be reached as to the possible advantage of one or other inhaled steroid.

\section{References}

1 Godfrey S. Konig P. Beclomethasone aerosol in childhood asthma. Arch Dis Child 1973;48:665-70.

2 Godfrey S. Konig P. Treatment of childhood asthma for 13 months and longer with beclomethasone dipropionate acrosol. Arch Dis Child 1974:49:591-6.

${ }^{3}$ Godfrey S, Balfour-Lynn L, Tooley M. A three to five year follow up of the use of aerosol steroid, beclomethasone dipropionate, in childhood asthma. J Allergy Clin Immunol 1978:62:335-9.

${ }^{4}$ Richards W, Platzker A. Church JA, Yamamoto F, Foster S. Steroid dependent asthma treated with inhaled beclomethasone dipropionatc in children. Ann Allergy 1978;41:274-7.

${ }^{5}$ Willey RF, Godden DJ, Carmichael J, Preston P, Frame M, Crompton GK. Comparison of twice daily administration of a new corticosteroid budesonide with beclomethasone dipropionate four times daily in the treatment of chronic asthma. BrJ Dis Chest 1982;76:61-8.

${ }^{6}$ Field HV, Jenkinson PMA, Frame MH, Warner JO. Asthma treatment with a new corticosteroid twice daily by a spacer inhaler. Arch Dis Child 1982;57:864-6.

${ }^{7}$ Kjellman M, Moller C, Glannow C, Konal A. A comparison of becotide and budesonide in children. Eur $J$ Respir Dis 1982;63(suppl 124): 127.

${ }^{8}$ Hyatt R, Waschek J, Weinberger M. Sherman B. Effects of inhaled beclomethasone dipropionate and alternate day prednisone on pituitary-adrenal function in children with chronic asthma. N Engl J Med 1978;299:1387-94.
9 Vaz R. Senior B. Morris M. Binkiewicz A. Adrenal effects of beclomethasone inhalation therapy in asthmatic children. J Pediatr 1982;100:660-2.

10 Connolly N. Godfrey S. Assessment of the child with asthma Journal of Asthma Research 1970:8:31-6.

1 Aranoff G. Rosler A. Urinary tetrahydrocortisone and tetrahydrocortisol glucosiduronates in normal newborns, children and adults. Acta Endocrinol 1980;94:371-5.

12 Rosler A, Rabinowitz D, Theodor R, Raminez LC, Ulick S. The nature of the defect in a salt wasting disorder in Jews of Iran. J Clin Endocrinol Metab 1977:44:279-83.

${ }^{13}$ Schumert Z, Rosenman A, Landau H, Rosler A. 11. deoxycortisol in amiotic fluid: prenatal diagnosis of congenital adrenal hyperplasia due to 11 hydroxylase deficency. Clin Endocrinol 1979;12:257-61.

14 Jubiz W. Meikle AW, West CD. Tyler FH. Single dose metyrapone test. Arch Intern Med 1970;125:472-4.

15 Berson SA, Yalow RS. Radioimmunoassay of ACTH in plasma. J Clin Invest 1968;47:2725.

${ }^{16}$ Meltzer EO, Orgel HA, Kemp JP. Chubb JM. Ward JF. Effect of dosing schedule on efficacy and safety of beclomethasone dipropionate aerosol (BDP) in chronic asthma. J Allergy Clin Immunol 1983:71:149.

17 Law CM, Marchant JL. Honour JW. Preece MA, Warner JO Nocturnal adrenal suppression in asthmatic children taking inhaled beclomethasone dipropionate. Lancet 1986;i:942-4.

Correspondence to Professor S Godfrey. Department of Pacdiatrics. Hadassah University Hospital, Mount Scopus, POB 24035. Jerusalem 91240. Israel.

Received 25 February 1987 